Pedro F. C. Vasconcelos 1

Amélia P. A. Travassos da Rosa 1,2 Sueli G. Rodrigues 1

Elizabeth S. Travassos da Rosa 1

Nicolas Dégallier 1,3

Jorge F. S. Travassos da Rosa 1

\section{Inadequate management of natural ecosystem in the Brazilian Amazon region results in the emergence and reemergence of arboviruses}

\author{
Gestão imprópria do ecossistema natural \\ na Amazônia brasileira resulta na emergência \\ e reemergência de arbovírus
}

1 World Health Organization Collaborating Center for Reference and Research on Arboviruses, Department of Arbovirus, Instituto Evandro Chagas, Fundação Nacional de Saúde, Ministério da Saúde. Av. Almirante Barroso 492 Belém, PA 66090-000, Brasil. 2 Department of Pathology, University of Texas Medical Branch. Galveston, Texas 77555-0609, USA. 3 Institut de Recherche pour le Developement, C.P. 7091, Brasília, DF 71619-970, Brasil.

\begin{abstract}
A total of 187 different species of arboviruses and other viruses in vertebrates were identified at the Evandro Chagas Institute (IEC) from 1954 to 1998, among more than 10,000 arbovirus strains isolated from humans, hematophagous insects, and wild and sentinel vertebrates. Despite intensive studies in the Brazilian Amazon region, especially in Pará State, very little is known about most of these viruses, except for information on date, time, source, and method of isolation, as well as their capacity to infect laboratory animals. This paper reviews ecological and epidemiological data and analyzes the impact of vector and host population changes on various viruses as a result of profound changes in the natural environment. Deforestation, mining, dam and highway construction, human colonization, and urbanization were the main manmade environmental changes associated with the emergence and/or reemergence of relevant arboviruses, including some known pathogens for humans.
\end{abstract}

Key words Arboviruses; Amazonian Ecosystem; Vectors' Ecology; Urbanization; Public Health

Resumo Um total de 187 diferentes espécies de arbovírus, além de outros vírus de vertebrados, foram identificados pelo Instituto Evandro Chagas (IEC) no período de 1954 a 1998, entre as mais de 10.000 cepas de vírus isoladas de seres humanos, insetos hematófagos e vertebrados-sentinela e silvestres. Apesar dos estudos intensivos realizados na Amazônia brasileira, sobretudo no Estado do Pará, pouco se sabe a respeito da maioria desses vírus, com exceção de dados a respeito de data, hora, fonte e método de isolamento, assim como a capacidade de infectar animais laboratoriais. Os autores fazem uma revisão dos dados ecológicos e epidemiológicos e procuram associar o impacto, sobre os diversos vírus, das mudanças populacionais dos vetores e hospedeiros induzidas por profundas alterações no meio ambiente. O desmatamento, o uso do subsolo, a construção de represas e de rodovias, a colonização humana e a urbanização foram as principais modificações ambientais introduzidas pelo homem e associadas à emergência ou reemergência de importantes arbovírus, inclusive alguns com atividade patogênica em seres humanos. Palavras-chave Arbovírus; Ecossistema Amazônico; Ecologia de Vetores; Urbanização; Saúde Pública 


\section{Introduction and historical background}

Arbovirus studies conducted in many areas of the Brazilian Amazon region over the past 44 years (1954-1998) have identified a large number of viruses. At least 187 different arboviruses have been isolated for a total of more than 10,000 times (a world record). Such large numbers of viruses is due to the fact that this region contains an astounding diversity of both arthropods and terrestrial and arboreal vertebrates and an essentially endless variety of ecological conditions, not to mention the efforts by energetic and enthusiastic personnel working at the Evandro Chagas Institute (IEC).

Thirty-two of these agents are known to be pathogenic to humans, causing fever, exanthematic fever, hemorrhagic disease, and encephalitis. Four of the viruses are relevant to public health because of their ability to cause severe human illness or even death and because they are also involved in epidemics (Vasconcelos et al., 1992). These four are dengue, yellow fever, Mayaro, and Oropouche. Dengue is associated with febrile exanthematic illness, in addition to its potential for causing hemorrhagic fever. Mayaro is also associated with febrile exanthematic disease. Yellow fever is the only arboviral hemorrhagic disease found in the region, while Oropouche causes a febrile illness sometimes accompanied by aseptic meningitis. Oropouche and dengue are active in urban areas, while Mayaro and yellow fever occur mainly in rural areas. Twenty-eight other arboviruses have been involved with febrile illness causing few or sporadic cases (Vasconcelos et al., 1992) (Table 1).

\section{Methods}

Samples collected from different sites were processed for virus isolation as follows: blood and viscera of vertebrates and pools of mosquitoes were stored in a mechanical freezer $\left(-70{ }^{\circ} \mathrm{C}\right.$ or lower) until processed for virus isolation in the laboratory. Samples were thawed and tissue homogenized thoroughly, using mortars and pestles into the containment cabinet, and diluted in a phosphate borate saline (PBS) solution with pH 7.4 containing $0.4 \%$ of bovine albumin (fraction $\mathrm{V}$ ), streptomycin $(100 \mu \mathrm{g} / \mathrm{ml})$, and penicillin $(100 \mathrm{IU} / \mathrm{ml})$. Homogenates were centrifuged at $1,000 \mathrm{~g}$ for ten minutes and the supernatants were inoculated into six suckling mice per cage. The inoculated animals were observed daily for three weeks. If signs of disease were observed, one to two animals were sampled.
The isolated strains were subsequently identified using panels of hyperimmune ascitic fluid or serum for the strain and known arboviruses using complement fixation, hemagglutination-inhibition, immunofluorescence, and neutralization, as previously described (Beaty et al., 1989).

\section{Summary of principal findings for arboviruses infecting humans}

\section{Ecological aspects}

Arboviruses are maintained in nature in cycles involving preferential hematophagous arthropod vectors and vertebrate hosts (WHO, 1985). These viruses are transmitted biologically by their vectors to susceptible vertebrate hosts. The amplifying vertebrate host develops viremia of sufficient titer and duration to infect subsequently feeding vectors. Vector infection is typically lifelong, with no apparent ill effects. Certain arboviruses may be transmitted transovarially and venereally by their arthropod vectors (WHO, 1985).

Occasional hematophagous arthropods may serve as arbovirus vectors. Known vectors include mosquitoes, ticks, sandflies, midges, and possibly mites. Two types of vertebrate hosts are of particular importance: those that serve as sources of vector infection and those that do not but in which overt disease occurs. From an epidemiological standpoint, the former are of primary interest, because together with the vector they serve as reservoirs, disseminators, and amplifiers of arboviruses. Human infection is usually a biological accident, and humans are typically dead-end or tangential hosts for the virus. Except for the urban yellow fever, dengue, and Oropouche viruses, humans do not appear to play an essential or important role in the maintenance and dissemination of arboviruses in the Amazon region (Vasconcelos et al., 1992).

Except for dengue, the arboviruses isolated in the Brazilian Amazon are maintained by different cycles, some complex and not wellknown, involving many vectors and vertebrate hosts. Thus, dengue virus has a simple cycle whereby the serotypes are directly transmitted to humans by Aedes aegypti mosquito bites. Oropouche virus is transmitted to man in urban areas by the biting midges Culicoides paraensis, while sloths, monkeys, and wild birds may play an important role in its maintenance cycle (Pinheiro et al., 1981a). Mayaro and yellow fever viruses in the jungle are mainly trans- 
Arboviruses isolated in the Brazilian Amazon region associated with human disease listed by type of disease and source of isolation, 1954-1998.

\begin{tabular}{|c|c|c|c|c|c|c|c|c|}
\hline type of disease & genus & antigenic group & virus & Nat. Acq. & Lab. Acq. & wild host & sentinel & arthropod \\
\hline Hemorrhagic & Flavivirus & $B$ & Yellow fever* & + & - & + & + & + \\
\hline Febrile illness & Alphavirus & $A$ & Mucambo & + & - & + & + & + \\
\hline$"$ & Alphavirus & $A$ & Pixuna & - & + & - & + & + \\
\hline$"$ & Bunyavirus & Anopheles A & Tacaiuma & + & - & + & - & + \\
\hline$"$ & Bunyavirus & Bunyamwera & Xingu & + & - & - & - & + \\
\hline$"$ & Bunyavirus & C & Apeu & + & - & + & + & + \\
\hline " & Bunyavirus & C & Caraparú & + & + & + & + & + \\
\hline " & Bunyavirus & C & Itaqui & + & - & + & + & + \\
\hline " & Bunyavirus & C & Marituba & + & - & + & + & + \\
\hline " & Bunyavirus & C & Murutucu & + & - & + & + & + \\
\hline$"$ & Bunyavirus & C & Nepuyo & - & - & + & + & + \\
\hline$"$ & Bunyavirus & C & Oriboca & + & - & + & + & + \\
\hline " & Bunyavirus & California & Guaroa & + & - & - & - & + \\
\hline$"$ & Bunyavirus & Guama & Catu & + & - & + & + & + \\
\hline " & Bunyavirus & Guama & Guama & + & - & + & + & + \\
\hline " & Bunyavirus & Simbu & Oropouche* & + & + & + & + & + \\
\hline " & Flavivirus & B & Bussuquara & - & - & + & + & + \\
\hline " & Flavivirus & B & Ilhéus & + & - & + & + & + \\
\hline " & Phlebovirus & Phlebotomus & Alenquer & + & - & - & - & + \\
\hline$"$ & Phlebovirus & Phlebotomus & Candiru & + & - & - & - & + \\
\hline$"$ & Phlebovirus & Phlebotomus & Morumbi & + & - & - & - & - \\
\hline$"$ & Phlebovirus & Phlebotomus & Serra Norte & + & - & & - & - \\
\hline " & Vesiculovirus & VSV & Jurona & + & - & - & - & + \\
\hline$"$ & Vesiculovirus & VSV & Piry & - & + & - & + & - \\
\hline Febrile rash & Alphavirus & $A$ & Mayaro* & + & + & + & + & + \\
\hline$"$ & Flavivirus & B & Dengue $1^{\star}$ & + & - & - & - & + \\
\hline " & Flavivirus & B & Dengue $2^{*}$ & + & - & - & - & + \\
\hline$"$ & Flavivirus & B & Dengue $4^{*}$ & + & - & - & - & + \\
\hline Encephalitis & Alphavirus & $A$ & EEE & - & - & + & + & + \\
\hline " & Alphavirus & A & WEE & - & - & + & + & + \\
\hline " & Bunyavirus & Bunyamwera & Tucunduba & + & - & - & - & + \\
\hline " & Flavivirus & B & SLE & + & - & + & + & + \\
\hline
\end{tabular}

* Responsible for epidemics in Brazilian Amazon.

mitted by the Haemagogus janthinomys mosquito, and monkeys are the main hosts (Pinheiro et al., 1981b). Indeed, Haemagogus albomaculatus, Sabethes chloropterus, Sabethes soperi, Aedes fulvus, and others have been found infected less frequently with yellow fever virus (Dégallier et al., 1992b; Vasconcelos et al., 1997).

\section{Epidemiological aspects}

The epidemiology of each arbovirus disease is determined by the preferred vector-vertebrate natural cycle. Arbovirus activity is clas- sified as enzootic, involving sporadic or intermittent cases, or epizootic, involving significant outbreaks (WHO, 1985). Infections with arbovirus maintained in enzootic cycles are generally caused by human (or animal) impingement on the natural cycle; such virus cycles are designated as rural, sylvatic, or jungle cycles. Infections during epidemics typically result when an arbovirus is introduced into a susceptible vertebrate population associated with a competent vector population. This is usually associated with natural cyclical conditions, such as heavy rain- 
fall, which are conducive to intense vector breeding (Shope, 1997).

Outbreaks of febrile disease have provided opportunities to find arboviruses in humans and domestic animals. These early studies revealed active yellow fever, Mayaro, Eastern equine encephalitis (in horses), and Oropouche viruses (Vasconcelos et al., 1992).

Epidemics have been reported in the States of Amazonas, Pará, Rondônia, and Roraima. Unplanned urbanization is the most important factor for the reemergence of dengue in the Amazon region. Dengue fever epidemics are now occurring in those States, but hemorrhagic cases have not been reported to date (Vasconcelos, 1999b).

Oropouche virus, transmitted to humans by the biting midge Culicoides paraensis, has been responsible for large epidemics in almost all States of the Amazon region and has infected approximately 500,000 inhabitants (Pinheiro et al., 1981a, 1998).

Mayaro virus has been responsible for small epidemics of febrile exanthematic illness in rural population of the Amazon region, since its vector, Haemagogus janthinomys, is a sylvatic mosquito that is rarely seen outside of the forest (Pinheiro et al., 1981b; Pinheiro \& Le Duc, 1988; Vasconcelos et al., 1992).

Yellow fever virus has been responsible for epidemics of hemorrhagic fever in the Amazon region, and non-immune individuals entering the forest are infected with increased frequency during the rainy season (Vasconcelos et al., 1997).

Twenty-eight other arboviruses have been involved with febrile illnesses causing few or sporadic cases (Table 1). Among these, the most important and prevalent based on serological surveys conducted in the Amazon Basin are Eastern equine, Western equine, and Saint Louis encephalites, Mucambo, Guaroa, Tacaiuma, group C, and Guama viruses (Vasconcelos et al., 1992; Shope et al., 1998).

It is important to emphasize that different arboviruses can be transmitted by the same mosquito species and can also infect different species of vertebrates, including humans. A single virus can also infect and be transmitted by several species of mosquitoes of different genera (Woodall, 1967; Travassos da Rosa et al., 1986). For example, the main sylvatic vector for yellow fever in the Amazon region as previously mentioned is Haemagogus janthinomys, but it may also be transmitted by other sylvatic Haemagogus, Sabethes, and Aedes mosquitoes to monkeys and possibly to humans (Dégallier et al., 1992b; Vasconcelos et al., 1997). In addition,
Haemagogus janthinomys is frequently found infected with the Mayaro virus, and also with Tacaiuma, Jurona, and other viruses (Woodall, 1967; Dégallier et al., 1989, 1992a). Table 2 summarizes these data for yellow fever and several other arboviruses. This is important for understanding the complex relationships of these arboviruses to the environment and to help explain the complexity of their ecology, epidemiology, and maintenance cycles.

Another key aspect is human participation in these cycles. In general humans are infected incidentally when they invade the viruses' ecological niches. Therefore, with the exception of the four viruses associated with epidemics and which cause considerable economic and social impacts, including fatal outcomes (as observed for dengue and yellow fever), the real involvement of these arboviruses as systematic agents of human disease is unknown in the Amazon region (Vasconcelos et al., 1992).

Nonetheless, several arboviruses are extremely widespread, reaching all of the Americas in some cases, like the Eastern equine, Western equine, and Saint Louis encephalitis viruses, important etiologic agents of central nervous system disease in humans (and also in equines in the case of the first two viruses). Migratory birds have been incriminated as carrying these arboviruses over long distances, with seasonal climatic changes being associated with this migration and ultimately for emergence of the viruses (Luby, 1979; Morris, 1988; Reisen \& Monath, 1988; Vasconcelos et al., 1991).

\section{Environmental management and emergence and reemergence of arboviruses}

Environmental changes can involve natural cyclical climatic modifications or the result of human endeavors such as deforestation, dam and highway construction, and mining.

In the Brazilian Amazon region, according to comparative studies conducted in the 1970s and 80s in Altamira and Tucuruí counties before, during, and after the construction of a dam in Tucuruí, Pará State (Pinheiro et al., 1977; Dégallier et al., 1992a), inadequate environmental management can disrupt the forest's stable state, leading to a series of phenomena including the increased incidence of known viruses or the emergence of new ones. Table 3 provides examples of arboviruses that emerged or reemerged in the Brazilian Amazon region and the factors explaining this emergence/ reemergence (Vasconcelos, 1999a). Many hu- 
Examples of association between arboviruses of different taxonomies, vectors, and hosts, including humans.

\begin{tabular}{|c|c|c|c|c|}
\hline Arboviruses & Taxonomy & Vectors & Hosts & $\begin{array}{l}\text { Infect } \\
\text { humans }\end{array}$ \\
\hline Yellow fever & $\begin{array}{l}\text { Flaviviridae } \\
\text { Flavivirus }\end{array}$ & $\begin{array}{l}\text { Haemagogus janthinomys*, } \\
\text { Haemagogus albomaculatus, } \\
\text { Sabethes cyaneus chloropterus, } \\
\text { other Hg. and Sa., and other } \\
\text { mosquitoes }\end{array}$ & $\begin{array}{l}\text { Monkeys, possibly } \\
\text { marsupials }\end{array}$ & Yes \\
\hline SLE & $\begin{array}{l}\text { Flaviviridae } \\
\text { Flavivirus }\end{array}$ & $\begin{array}{l}\text { Culex declarator }{ }^{\star} \text {, Culex coronator, } \\
\text { Aedes serratus, and others }\end{array}$ & $\begin{array}{l}\text { Migratory and non- } \\
\text { migratory birds }\end{array}$ & Yes \\
\hline Oropouche & $\begin{array}{l}\text { Bunyaviridae } \\
\text { Bunyavirus }\end{array}$ & $\begin{array}{l}\text { Culicoides paraensis*, Culex } \\
\text { quinquefaciatus, and possibly } \\
\text { Aedes serratus and Coquilettidia } \\
\text { venezuelensis }\end{array}$ & $\begin{array}{l}\text { Sloths, monkeys, } \\
\text { and birds }\end{array}$ & Yes \\
\hline Gamboa & $\begin{array}{l}\text { Bunyaviridae } \\
\text { Bunyavirus }\end{array}$ & $\begin{array}{l}\text { Aedeomyia squamipennis*, } \\
\text { Anopheles triannulatus }\end{array}$ & Migratory birds & No \\
\hline Tacaiuma & $\begin{array}{l}\text { Bunyaviridae } \\
\text { Bunyavirus }\end{array}$ & $\begin{array}{l}\text { Hg. janthinomys*, Anopheles } \\
\text { (Nys.) triannulatus, Aedes scapularis }\end{array}$ & Monkeys & Yes \\
\hline $\begin{array}{l}\text { Other Anopheles } \\
\text { A group viruses }\end{array}$ & $\begin{array}{l}\text { Bunyaviridae } \\
\text { Bunyavirus }\end{array}$ & $\begin{array}{l}\text { Anopheles (Nyss) nuneztovari*, } \\
\text { An. oswaldoi and An. triannulatus }\end{array}$ & Unknown & No \\
\hline Group C & $\begin{array}{l}\text { Bunyaviridae } \\
\text { Bunyavirus }\end{array}$ & $\begin{array}{l}\text { Culex (Mel.) sp, Culex portesi, } \\
\text { Culex vomerifer, other Culex } \\
\text { Aedes, Coquilettidia, Limatus, } \\
\text { Psorophora, etc. }\end{array}$ & $\begin{array}{l}\text { Rodents and } \\
\text { marsupials }\end{array}$ & Yes \\
\hline Group Guama & $\begin{array}{l}\text { Bunyaviridae } \\
\text { Bunyavirus }\end{array}$ & $\begin{array}{l}\text { Culex (Mel.) sp, Culex portesi*, } \\
\text { Culex vomerifer, other Cx. Ae., } \\
\text { Coq., Limatus, Psorophora, etc. }\end{array}$ & $\begin{array}{l}\text { Rodents and } \\
\text { marsupials }\end{array}$ & Yes \\
\hline EEE & $\begin{array}{l}\text { Togaviridae } \\
\text { Alphavirus }\end{array}$ & $\begin{array}{l}\text { Aedes taeniorhynchus }{ }^{\star}, \text { Culex } \\
\text { pedroi*, Culex (Cux.) sp and others }^{*}\end{array}$ & $\begin{array}{l}\text { Migratory and non- } \\
\text { migratory birds } \\
\text { and equines }\end{array}$ & Yes \\
\hline Mayaro & $\begin{array}{l}\text { Togaviridae } \\
\text { Alphavirus }\end{array}$ & $\begin{array}{l}\text { Haemagogus janthinomys } \\
\text { and possibly other Haemagogus } \\
\text { mosquitoes }\end{array}$ & $\begin{array}{l}\text { Monkeys, birds, } \\
\text { and possibly } \\
\text { other animals. }\end{array}$ & Yes \\
\hline Mucambo & $\begin{array}{l}\text { Togaviridae } \\
\text { Alphavirus }\end{array}$ & $\begin{array}{l}\text { Culex portesi*, Culex (Mel.) sp., } \\
\text { Culex (Cux.) sp, and others }\end{array}$ & $\begin{array}{l}\text { Rodents and } \\
\text { marsupials }\end{array}$ & Yes \\
\hline Triniti & $\begin{array}{l}\text { Togaviridae } \\
\text { ungrouped }\end{array}$ & $\begin{array}{l}\text { Sabethes sp, Wyeomyia sp*, } \\
\text { Trichoprosopon sp, Anopheles sp }\end{array}$ & Unknown & Not \\
\hline
\end{tabular}

* Most important vectors.

man activities can alter the forest's fragile equilibrium. The following section describes the most important factors in the Brazilian Amazon region.

\section{Deforestation for agriculture}

This practice has been incriminated for several decades in sylvatic yellow fever outbreaks in Latin America. In Brazil, extensive areas have been razed to open the land for cattle ranches, during which the tree felling attracts a large contingent of susceptible or non-immune in- dividuals from urban areas in search of work (Strode, 1951). Deforestation for cattle ranching has thus become the main factor in the reemergence and increase in reported yellow fever cases in Brazil in recent years (Vasconcelos et al., 1997; Vasconcelos et al., submitted). The spread of the Mayaro and Oropouche viruses may also have resulted partially from this practice (Pinheiro et al., 1981a, 1981b, 1998, 1994). 
Table 3

Emerging arboviruses and serogroups in the Brazilian Amazon region, probable factor(s) for their emergence, and association with human disease.

\begin{tabular}{|c|c|c|}
\hline Virus/groups & Probable factors for emergence & Disease in humans \\
\hline \multicolumn{3}{|l|}{ Viruses } \\
\hline Dengue & $\begin{array}{l}\text { Poor mosquito control; } \\
\text { increased urbanization in tropics }\end{array}$ & Yes, epidemic \\
\hline Gamboa & $\begin{array}{l}\text { Hydroelectric dam*; } \\
\text { migratory birds }\end{array}$ & Not to date \\
\hline Guaroa & Hydroelectric dam* & Yes, sporadic cases \\
\hline Mayaro & Deforestation & Yes, limited outbreak \\
\hline Oropouche & $\begin{array}{l}\text { Deforestation;increased human } \\
\text { colonization and urbanization } \\
\text { in Amazon }\end{array}$ & Yes, epidemic \\
\hline Triniti & Hydroelectric dam* & Not to date \\
\hline Yellow fever & $\begin{array}{l}\text { Urbanization in tropics; } \\
\text { deforestation;lack of wide } \\
\text { spread immunization }\end{array}$ & Yes, epidemic \\
\hline \multicolumn{3}{|l|}{ Serogroups } \\
\hline Anopheles A1 & Hydroelectric dam* & Not to date \\
\hline Changuinola2 & $\begin{array}{l}\text { Hydroelectric dam*; } \\
\text { deforestation; mining }\end{array}$ & Not to date \\
\hline
\end{tabular}

* During dam construction in Tucuruí, Pará State, millions of hematophagous insects were obtained in a few days, from which several strains of previously known and new viruses were obtained.

1 In this serogroup from the Bunyaviridae family, the new virus species Arumateua, Caraipé, and Tucuruí were isolated, and increased circulation of the Lukuni, Tacaiuma, and Trombetas viruses occurred.

2 In this serogroup from the Reoviridae family, 27 new virus species were isolated in Tucuruí, four in Carajás (associated with pit mining), and 8

in Altamira (deforestation for several purposes) from phlebotomine sandflies.

\section{Highway construction}

During the early 1970s, construction began on an extensive network of highways across vast areas of virgin tropical forest in the Amazon region of Brazil. Studies were conducted at numerous sites along these highways to determine the possible occurrence of arboviruses and to assess their public health relevance. As a result, a number of arboviruses were isolated, some known previously and others new to science. The new viruses included six members of the Phlebotomus fever serogroup (family $\mathrm{Bu}$ nyaviridae, genus Phlebovirus), 12 members of the Changuinola serogroup (Reoviridae, genus Orbivirus), five members of several serogroups from the family Bunyaviridae (genus Bunyavirus), four viruses belonging to other families, and six ungrouped viruses (Pinheiro et al., 1977; Dégallier et al., 1992a; Travassos da Rosa et al., 1992a, 1998).

\section{Dam construction}

A dam was built in the 1980s in the Tucuruí area of Pará State, flooding large areas of tropical forest. During the three-month period in which the Tucuruí area was flooded, over one million mosquitoes and phlebotomine sandflies were captured. A large number of new viruses were isolated from these arthropods. In the 1990s, studies were carried out at the Balbina (Amazonas State) and Samuel (Rondonia State) dams, adding further new viruses to science. Dozens of new viruses were isolated, including four members of the Phlebotomus serogroup, 30 from the Changuinola serogroup, three from the Anopheles A serogroup, one from the Gamboa serogroup (family Bunyaviridae, genus Bunyavirus), six unclassified viruses, and one Togaviridae (genus Alphavirus) (Dégallier et al., 1989, 1992a; Vasconcelos, 1999a; Travassos da Rosa et al., 1992b). The impact of the increase in arthropod populations is illustrated by the Gamboa virus isolated at Tucuruí, where the ornithophilic mosquito species Aedeomyia squamipennis had not been observed before the flooding. During and after flooding the reservoir area, large numbers of this species were obtained. Inoculation of these mosquitoes provided isolation of 91 strains of Gamboa-like virus. During the same period, three strains of Gamboa-like virus were isolated from various avian species. It is worthy of note that this virus had not been isolated previously in Brazil. Environmental change was thus responsible for the emergence of this virus (Dégallier et al., 1992a; Vasconcelos, 1999a).

This example clearly illustrates the emergence of a new virus in a region where intensive studies in 1982-84, prior to the change in the environment, had not identified its presence. Other alterations in the ecosystem occurred in this area, involving hematophagous arthropods and wild vertebrates, but the full chain of events is uncertain (Vasconcelos, 1999a).

\section{Colonization/urbanization}

Colonization of new areas in the wake of highway construction, with major demographic flux and environmental change, has been associated with the spread of viruses. One can expect that outbreaks in these settlements will occur as the population increases, resulting from susceptible people living and working close to the forests and exposed to large numbers of infected vectors (Pinheiro et al., 1977).

The Oropouche virus is the best documented example in this category. Dwellings built af- 
ter clearing forest areas have been suggested as the main factor in the emergence of Oropouche virus epidemics in the Brazilian Amazon region (Pinheiro et al., 1981a, 1998; Le Duc \& Pinheiro, 1988). Numerous susceptible individuals enter peripheral areas, and many enter the forest (and possibly the virus's epidemiological niche) searching for food, clearing new areas, and extracting forest products. During such activities, contact between infected vectors and susceptible individuals is facilitated and transmission can occur; the infected individual returns to the community, where an epidemic transmission cycle can be established without wild or domestic vertebrates if the urban vector (Culicoides paraensis) is present. Evidence for this hypothetical mechanism has been observed and proposed as a plausible explanation for the explosive epidemics and the extensive spread of Oropouche virus in the Amazon basin (Pinheiro et al., 1981a, 1994).

\section{Use of land and subsoil}

Improper mining practices and inadequate land use can facilitate contact between humans, vectors, and arboviruses. For example, gold miners entering the forest have caused environmental hazards like mercury pollution on land and in the rivers, besides fostering mosquito replication. In the early 1990s, large contingents of miners moved from several places (especially from the Serra Pelada mining area) to the Yanomami Indian reservation in extensive areas of Amazonas and Roraima States.

Illegal activity by miners was responsible for intense environmental modification that resulted in the introduction and/or transmission of several diseases that had never been diagnosed among the Yanomami (malaria, hepatitis B/D, and yellow fever). In 1991, about a year after miners invaded their territory, environmental changes were followed by a yellow fever epidemic. Since then this virus has been diagnosed periodically among the Yanomami, with a high case-fatality rate (Dégallier et al., 1992b; Instituto Evandro Chagas, 1996, 1999).

In the Carajás area, studies conducted by the IEC from 1982 to 1987 revealed a rich fauna of wild vertebrates and arthropods that furnished several strains of arboviruses, some new to science. This region harbors ecosystems rich in arboviruses, and natural resources must be exploited carefully and rationally to avoid outbreaks from the current foci of infestation existing in the forest (Travassos da Rosa et al., 1992a).
Studies in Carajás and several other areas (Jari, Porto Trombetas, Cachoeira Porteira, and Santana) with mining projects led to the isolation of 24 new viruses, among which four members of the Phlebotomus fever serogroup, 11 from the Changuinola serogroup, six from other families (two Rhabdoviridae, genus Vesiculovirus, and one each from Arenaviridae, Bunyaviridae, Flaviviridae, and Paramyxoviridae), and four unclassified viruses (Travassos da Rosa et al., 1992a, 1998; Instituto Evandro Chagas, 1996, 1999).

\section{Climate and seasonal occurrence}

Reported epidemics caused by arboviruses have been documented in the first half of the year. Oropouche virus outbreaks have occurred from March to July (Linley, 1983). This occurrence is intrinsically associated with climate change and increased rainfall, which is heavier in the Amazon during the first half of the year. Increased rainfall thus contributes to reproduction of hematophagous arthropod arbovirus vectors, and if other epidemiological factors are present, epidemics can occur. For example, yellow fever and Mayaro epidemics have also been reported more frequently in the first half of the year (Pinheiro et al., 1981b; Pinheiro \& Le Duc, 1988; Vasconcelos et al., 1997). Table 4 shows examples of arbovirus epidemics and seasonal occurrence.

\section{Discussion and conclusions}

Arboviruses occur naturally in the Amazon forest, but they depend on complex mechanisms for their maintenance (Brés, 1988). The broad biodiversity in terms of number of species and quantity of individuals for each species in the Brazilian Amazon is the key factor in the region's large number of arboviruses (Vasconcelos et al., 1992).

Regarding manmade environmental changes, it is important to emphasize that when large forest areas are razed and/or flooded during dam construction, arthropod vectors and wild animals, the two main factors in the arbovirus sylvatic maintenance cycle, must adapt quickly or die. Obviously, arboviruses harbored by them tend to disappear quickly, since the ecotope of several arboviruses is limited, that is, their distribution is focal, restricted to small ecotopes or ecological niches (Reeves, 1963; Vasconcelos et al., 1992).

Consequently, any modification in the environment can take two different directions: if 
Epidemics caused by arboviruses, place, and period of their occurrence in the Brazilian Amazon region, $1973-1999$.

\begin{tabular}{|c|c|c|c|}
\hline Arbovirus & State & County(ies) & Period \\
\hline \multirow[t]{8}{*}{ Yellow fever } & Goiás & About 30 counties & 1st half 1973 \\
\hline & Pará & Monte Alegre, Faro and Alenquer & March-May 1984 \\
\hline & Roraima & Yanomami Indian village & Nov.-Dec. 1991 \\
\hline & Mato Grosso do Sul & Several counties near Campo Grande & 1st half 1991 \\
\hline & Maranhão & Mirador, Pastos Bons, and others & 1st half 1993-94 \\
\hline & Amazonas & Seven counties near Manaus & 1st half 1996 \\
\hline & Roraima & Alto Alegre and near Boa Vista & 1st half 1998 \\
\hline & Pará & Afuá and Breves & 1st half 1998-99 \\
\hline \multirow[t]{5}{*}{ Mayaro } & Pará & Belterra & Dec.1977-Apr. 78 \\
\hline & Pará & Conceição do Araguaia & 1st half 1981 \\
\hline & Goiás & Itaruma & Jan.-Mar. 1987 \\
\hline & Tocantins & Peixe & Apr. 1991 \\
\hline & Pará & Benevides & Feb.-Apr. 1991 \\
\hline \multirow[t]{11}{*}{ Oropouche } & Pará & $\begin{array}{l}\text { Santarém and several neigh } \\
\text { boring counties }\end{array}$ & Feb.-Aug. 1975 \\
\hline & Pará & Tomé-Açu & June-Oct. 1978 \\
\hline & Pará & $\begin{array}{l}\text { Belém and several neigh } \\
\text { boring counties }\end{array}$ & Feb.-Oct. 1979-80 \\
\hline & Amazonas & Manaus and Barcelos & Nov. 1980-July 81 \\
\hline & Amapá & Mazagão & 1st half 1981 \\
\hline & Maranhão & Porto Franco and Estreito & 1st half 1988 \\
\hline & Rondônia & Ariquemes and Ouro Preto D'oeste & Mar.-June 1991 \\
\hline & Pará & Serra Pelada & Nov.-Dec. 1994 \\
\hline & Acre & Xapurí & 1st half 1996 \\
\hline & Pará & Oriximiná and Altamira region & Feb.-June 1996 \\
\hline & Amazonas & Novo Airão & 1st half 1996 \\
\hline
\end{tabular}

the change is positive for virus survival, the arbovirus spreads and can infect humans, or if it already was infecting humans, it can cause limited or explosive epidemics, depending on the distribution and abundance of its vectors. However, if environmental changes are negative for the virus, the latter tends to disappear (Reeves, 1963; Vasconcelos et al., 1992).

The former hypothesis is the most probable explanation for the explosive epidemics of Oropouche fever in Pará State in the 1960s and 70 s, as well as in other States of the Amazon region and other Latin American countries in the 1980s and 90s (Table 4), as observed in Peru and Panama (Pinheiro et al., 1981a, 1998; Watts et al., 1998). Table 2 shows the most important observations on the circulation of several arboviruses in the Brazilian Amazon region and the possible factors involved in their emergence or reemergence.

The latter hypothesis is more difficult to prove. But it is the most plausible explanation for the silence of many virus species isolated only once or a few times, from which no further signs of activity were observed. This may be especially true for those arboviruses whose vectors are anthropophilic and are widely distributed in the region.

Finally, it is clear that further studies are needed on intensive human migration, with colonization, mining, dam construction, and other activities that change the environment and modify established ecosystems in order to shed light on several aspects of the epidemiology, ecology, life cycles, and distribution of this group of viruses (Vasconcelos et al., 1992). Moreover, intervention in the biotopes is increasingly frequent, and research must be done to achieve reliable evaluations of these changes and their implications. Consequently, cross-analyzing information through this interface can result in valuable data and should answer many of those questions (Vasconcelos et al., 1992). 
To conclude, as Shope (1997:22) has stated emphatically: "It is safe to say that most emerging arbovirus diseases follow ecological modifications. It is naïve to think that humans will stop building cities and dams, or stop entering and destroying the forest. We can, however, learn more about risk and risk management; and we must continue to support environmental and health assessments, and begin to believe our scientifically based predictions and act on them."

\section{References}

BEATY, B. J.; CALISHER, C. H. \& SHOPE, R. E., 1989. Arboviruses. In: Diagnostic Procedures for Viral, Rickettsial, and Chlamydial Infections (N. J. Schmidt \& E. W. Emmons, eds.), 6th Ed., pp. 797855, Washington, D.C.: American Public Health Association.

BRÉS, P., 1988. Impact of arboviruses on human and animal health. In: The Arboviruses: Epidemiology and Ecology (T. P. Monath, ed.), v. I, pp. 1-18, Boca Ratón: CRC Press.

DÉGALLIER, N.; TRAVASSOS DA ROSA, A. P. A.; HERVÉ, J.-P.; VASCONCELOS, P. F. C.; TRAVASSOS DA ROSA, J. F. S.; SÁ FILHO, G. C. \& PINHEIRO, F. P., 1989. Modifications of arbovirus ecoepidemiology in Tucuruí, Pará, Brazilian Amazonia, related to the construction of a hydroelectric dam. In: Arbovirus Research in Australia. Proceedings of the 5th Symposium of the Queensland Institute of Medical Research (Queensland Institute of Medical Research, ed.), pp. 124-135, Brisbane: Queensland Institute of Medical Research.

DÉGALLIER, N.; TRAVASSOS DA ROSA, A. P. A.; VASCONCELOS, P. F. C.; HERVE, J.-P.; SÁ FILHO, G. C.; TRAVASSOS DA ROSA, J. F. S.; TRAVASSOS DA ROSA, E. S. \& RODRIGUES, S. G., 1992a. Modifications of arbovirus transmission in relation to construction of dams in Brazilian Amazonia. Journal of the Brazilian Association for the Advancement of Science, 44:124-135.

DÉGALLIER, N.; TRAVASSOS DA ROSA, A. P. A.; VASCONCELOS, P. F. C.; TRAVASSOS DA ROSA, E. S.; SÁ FILHO, G. C. \& TRAVASSOS DA ROSA, J. F. S, 1992b. New entomological and virological data on the vectors of sylvatic yellow fever in Brazil. Journal of the Brazilian Association for the Advancement of Science, 44:136-142.

INSTITUTO EVANDRO CHAGAS, 1996. Relatório Qüinqüenal, 1991-1995. Belém: Instituto Evandro Chagas.

INSTITUTO EVANDRO CHAGAS, 1999. Annual Report: 1995-1998. Belém: Instituto Evandro Chagas.

LE DUC, J. W. \& PINHEIRO, F. P., 1988. Oropouche fever. In: The Arboviruses: Epidemiology and Ecology (T. P. Monath, ed.), pp. 1-14, v. IV, Boca Ratón: CRC Press.

\section{Acknowledgments}

We thank ELETRONORTE, SUDAM, Companhia Vale do Rio Doce (CVRD), and the Ministry of Health for supporting this research, and Dr. Robert Tesh of the University of Texas Medical Branch for reviewing and commenting on the manuscript.
LINLEY, J. R.; HOCH, A. L. \& PINHEIRO, F. P., 1983. Biting midges (Diptera: Caratopogonidae) and human health. Journal of Medical Entomology, 20:347-364.

LUBY, J. P., 1979. St. Louis encephalitis. Epidemiologic Reviews, 1:55-73.

MORRIS, C. D., 1988. Eastern equine encephalomyelitis. In: The Arboviruses: Epidemiology and Ecology (T. P. Monath, ed.),v. III, pp. 1-20, Boca Ratón: CRC Press.

PINHEIRO, F. P. \& LE DUC, J. W., 1988. Mayaro fever. In: The Arboviruses: Epidemiology and Ecology (T. P. Monath, ed.), v. III, pp. 137-150, Boca Ratón: CRC Press.

PINHEIRO, F. P.; BENSABATH, G.; TRAVASSOS DA ROSA, A. P. A.; LAINSON, R.; SHAW, J. J.; FRAIHA, H.; MORAES, M. A. P.; GUEIROS, Z. M.; LINS, Z. C. \& MENDES, R., 1977. Public health hazards among workers along the Trans-Amazon Highway. Journal of Occupational Medicine, 19:490-497.

PINHEIRO, F. P.; TRAVASSOS DA ROSA, A. P. A.; TRAVASSOS DA ROSA, J. F. S.; ISHAK, R.; FREITAS, R. B.; GOMES, M. L. C.; LE DUC, J. W. \& OLIVA, O. F. P., 1981a. Oropouche virus. I. A review of clinical, epidemiological, and ecological findings. American Journal of Tropical Medicine and Hygiene, 30:149-160

PINHEIRO, F. P.; FREITAS, R. B.; TRAVASSOS DA ROSA, J. F. S.; GABBAY, Y. B.; MELLO, W. A. \& LE DUC, J. W., 1981b. An outbreak of Mayaro virus disease in Belterra, Brazil. I. Clinical and virological findings. American Journal of Tropical Medicine and Hygiene, 30:674-681.

PINHEIRO, F. P.; TRAVASSOS DA ROSA, A. P. A. \& VASCONCELOS, P. F. C., 1998. An overview of Oropouche fever epidemics in Brazil and neighbour countries. In: An Overview of Arbovirology in Brazil and Neighbouring Countries (A. P. A. Travassos da Rosa, P. F. C. Vasconcelos \& J. F. S. Travassos da Rosa, eds.), pp. 186-192, Belém: Instituto Evandro Chagas.

PINHEIRO, F. P.; TRAVASSOS DA ROSA, A. P. A. \& VASCONCELOS, P. F. C., 1994. Oropouche fever. In: CRC Handbook Series in Zoonoses; Section B. Viral Zoonoses (G. W. Beran, ed.), pp. 214-217, Boca Ratón: CRC Press. 
REEVES, W. C., 1963. General ecology of the arboviruses. Anais de Microbiologia (parte A), Rio de Janeiro, 11:37-44.

REISEN, W. K. \& MONATH, T. P., 1988. Western equine encephalomyelitis. In: The Arboviruses: Epidemiology and Ecology (T. P. Monath, ed.), pp. 89-137, v. V, Boca Ratón: CRC Press.

SHOPE, R. E., 1997. Emergence of arbovirus disease following ecological modifications: Epidemiological consequences. In: Factors in the Emergence of Arbovirus Diseases (J. F. Saluzzo \& B. Dodet, eds.), pp. 19-22, Paris: Elsevier.

SHOPE, R. E.; WOODALL, J. P. \& TRAVASSOS DA ROSA, A. P. A., 1988. The epidemiology of diseases caused by viruses in groups $\mathrm{C}$ and Guama (Bunyaviridae). In: The Arboviruses: Epidemiology and Ecology (T. P. Monath, ed.), v. III, pp. 37-52, Boca Ratón: CRC Press.

STRODE, G. K., 1951. Yellow Fever. New York: McGraw-Hill.

TRAVASSOS DA ROSA, A. P. A.; SHOPE, R. E.; TRAVASSOS DA ROSA, J. F. S.; NAKAUTH, C. M. \& VASCONCELOS, P. F. C., 1986. Aspectos virológicos dos arbovírus. In: Instituto Evandro Chagas: 50 anos de Contribuição às Ciências Biológicas e à Medicina Tropical (Instituto Evandro Chagas, ed.), v. 1, pp. 365-373, Belém: Fundação Serviços de Saúde Pública.

TRAVASSOS DA ROSA, A. P. A.; TRAVASSOS DA ROSA, J. F. S.; HERVÉ, J. P.; VASCONCELOS, P. F. C; DÉGALLIER, N. \& RODRIGUES, S. G., 1992a. Arboviruses in Serra Norte, Carajás region, Pará, Brazil. Journal of the Brazilian Association for the Advancement of Science, 44:158-161.

TRAVASSOS DA ROSA, J. F. S.; TRAVASSOS DA ROSA, A. P. A.; DÉGALLIER, N. \& VASCONCELOS, P. F. C., 1992b. Caracterização e relacionamento antigênico de três novos Bunyavirus do grupo Anopheles A (Bunyaviridade) dos arbovírus. Revista de Saúde Pública, 26:173-178.

TRAVASSOS DA ROSA, J. F. S.; TRAVASSOS DA ROSA, A. P. A.; VASCONCELOS, P. F. C.; PINHEIRO, F. P.; RODRIGUES, S. G.; TRAVASSOS DA ROSA, E. S.; DIAS, L. B. \& CRUZ, A. C. R., 1998. Arboviruses isolated in the Evandro Chagas Institute, including some described for the first time in the Brazilian Amazon region, their known hosts, and their pathology for man. In: An Overview of Arbovirology in Brazil and Neighbouring Countries (A. P. Travassos da Rosa, P. F. C. Vasconcelos \& J. F. S. Travassos da Rosa, eds.), pp. 19-31, Belém: Instituto Evandro Chagas.
VASCONCELOS, P. F. C., 1999a. Emergence of arboviruses in Brazilian Amazon region. Virus Review and Research, 4:48-49.

VASCONCELOS, P. F. C., 1999b. Estudo de Epidemias de Dengue. Uso e Significado dos Inquéritos Soroepidemiológicos Transversais. Tese de Doutorado, Salvador: Universidade Federal da Bahia.

VASCONCELOS, P. F. C.; TRAVASSOS DA ROSA, J. F. S.; TRAVASSOS DA ROSA, A. P. A.; DÉGALLIER, N.; PINHEIRO, F. P. \& SÁ FILHO, G. C., 1991. Epidemiologia das encefalites por arbovirus na Amazônia. Brasileira. Revista do Instituto de Medicina Tropical de São Paulo, 33:465-476.

VASCONCELOS, P. F. C.; TRAVASSOS DA ROSA, A. P. A.; DÉGALLIER, N.; TRAVASSOS DA ROSA, J. F. S. \& PINHEIRO, F. P., 1992. Clinical and ecoepidemiological situation of human arboviruses in Brazilian Amazonia. Journal of the Brazilian Association for the Advancement of Science, 44:117-124.

VASCONCELOS, P. F. C.; RODRIGUES, S. G.; DÉGALLIER, N.; MORAES, M. A. P.; TRAVASSOS DA ROSA, J. F. S.; TRAVASSOS DA ROSA, E. S.; MONDET, B.; BARROS, V. L. R. S. \& TRAVASSOS DA ROSA, A. P. A., 1997. An epidemic of sylvatic yellow fever in the southeast region of Maranhão State, Brazil, 1993-1994: Epidemiologic and entomological findings. American Journal of Tropical Medicine and Hygiene, 57:132-137.

VASCONCELOS, P. F. C.; TRAVASSOS DA ROSA, A. P. A.; RODRIGUES, S. G.; TRAVASSOS DA ROSA, E. S.; MONTEIRO, H. A. O.; CRUZ, A. C. R.; BARROS, V. L. R. S.; SOUZA, M. R. S. \& TRAVASSOS DA ROSA, J. F. S. Yellow fever in Pará State, Amazon region of Brazil, 1998-1999. Entomological and Epidemiological findings. Emerging Infectious Diseases. (Submitted)

WATTS, D. M.; RAMIREZ, G.; CABEZAS, C.; WOOSTER, M. T.; CARRILLO, C.; CHUY, M.; GENTRAU, E. J. \& HAYES, C. G., 1998. Arthropod-borne viral diseases in Peru. In: An Overview of Arbovirology in Brazil and Neighbouring Countries (A. P. A. Travassos da Rosa, P. F. C. Vasconcelos \& J. F. S. Travassos da Rosa, eds.), pp. 193-218, Belém: Instituto Evandro Chagas.

WHO (World Health Organization), 1985. Arthropodborne and Rodent-borne Viral Diseases. WHO Technical Report Series 719. Geneva: WHO.

WOODALL, J. P., 1967. Virus research in Amazonia. In: Atas do Simpósio sobre a Biota Amazônica (Patologia) (Conselho Nacional de Desenvolvimento Científico e Tecnológico-CNPq, org.), v. 6, pp. 31, Rio de Janeiro: CNPq. 